\title{
Modeling and Simulation of a Grid Connected Variable Speed Wind Energy Conversion System with Low Cost Power Converters
}

\author{
A. B. Raju, B. G. Fernandes, Kishore Chatterjee \\ Department of Electrical Engineering, \\ Indian Institute of Technology Bombay, \\ Powai, Mumbai-400 076, INDIA.
}

Phone:+91-22-25767428, Fax:+91-22-25723707,E-mail:bgf@ee.iitb.ac.in

\begin{abstract}
In this paper, modeling and simulation of a grid connected variable speed wind energy conversion system (VSWECS) with low cost power converters is presented. The system consists of a permanent magnet synchronous generator (PMSG), two pulse width modulated B-4 power converters and a maximum power point tracker (MPPT). Mathematical model of each element of the system is developed separately and then they are integrated to simulate the whole system for various wind velocities. The complete system has been simulated using MATLAB/SIMULINK and simulation results are presented.
\end{abstract}

\section{Key words}

Grid interface, modeling, power converters, simulation, wind energy

\begin{tabular}{|cll|}
\hline & & \multicolumn{1}{c|}{ Symbols } \\
\hline $\mathrm{r}$ & $:$ & Radius of the wind turbine rotor, $\mathrm{m}$ \\
$\mathrm{V}$ & $:$ & Velocity of the wind, $\mathrm{m} / \mathrm{s}$ \\
$\mathrm{\rho}$ & $:$ & Air density, $\mathrm{kg} / \mathrm{m}^{2}$ \\
$\mathrm{G}$ & $:$ & Gear ratio \\
$\mathrm{R}_{\mathrm{s}}$ & $:$ & Stator phase winding resistance, $\Omega$ \\
$\mathrm{L}_{\mathrm{q}}$ & $:$ & Quadrature axis stator inductance, $\mathrm{H}$ \\
$\mathrm{L}_{\mathrm{d}}$ & & Direct axis stator inductance, $\mathrm{H}$ \\
$\mathrm{L}_{\mathrm{sr}}$ & $:$ & Per phase inductance between PMSG \\
& & and rectifier, $\mathrm{H}$ \\
$\mathrm{L}_{\mathrm{si}}$ & $:$ & Per phase inductance between inverter \\
& & and grid, $\mathrm{H}$ \\
$\mathrm{R}$ & $:$ & Per phase resistance of coupling \\
& & inductance, $\Omega$ \\
$\mathrm{V}_{\mathrm{dg}}$ & $:$ & Direct axis stator terminal voltage, $\mathrm{V}$ \\
$\mathrm{V}_{\mathrm{qg}}$ & $:$ & Quadrature axis stator terminal \\
& & voltage, $\mathrm{V}$ \\
$\mathrm{i}_{\mathrm{d}}$ & & Direct axis stator current, A \\
$\mathrm{i}_{\mathrm{q}}$ & $:$ & Quadrature axis stator current, A \\
$\omega$ & $:$ & Wind rotor speed, rad/sec \\
$\lambda_{\mathrm{m}}$ & $:$ & Amplitude of the flux linkages \\
& & established by a PM as viewed from \\
& & the stator phase windings, V/rad/sec \\
$\mathrm{p}$ & $:$ & d/dt \\
$\mathrm{t}_{\mathrm{e}}$ & $:$ & Electromagnetic torque, Nm \\
$\mathrm{P}$ & $:$ & Number of poles on the rotor \\
& &
\end{tabular}

\begin{tabular}{|ccl|}
\hline $\mathrm{J}$ & $:$ & $\begin{array}{l}\text { Moment of inertia referred to the shaft } \\
\text { of the generator, kgm }\end{array}$ \\
$\mathrm{S}_{\mathrm{a}}, \mathrm{S}_{\mathrm{b}}$ & $:$ & Switching functions for the rectifier \\
$\mathrm{S}_{\mathrm{a}}, \mathrm{S}_{\mathrm{b}}$ & $:$ & Switching function for the inverter \\
$\mathrm{V}_{\mathrm{cl}}, \mathrm{V}_{\mathrm{c} 2}$ & $:$ & Voltage across capacitors $\mathrm{C}_{1}, \mathrm{C}_{2}, \mathrm{~V}$ \\
$\mathrm{i}_{\mathrm{cl}}, \mathrm{i}_{\mathrm{c} 2}$ & $:$ & Current through capacitors $\mathrm{C}_{1}, \mathrm{C}_{2}, \mathrm{~A}$ \\
$\mathrm{i}_{\mathrm{dcr} 1}$ & $:$ & Positive dc rail rectifier current, A \\
$\mathrm{i}_{\mathrm{dcr} 2}$ & $:$ & Negative dc rail rectifier current, A \\
$\mathrm{i}_{\mathrm{dci} 1}$ & $:$ & Positive dc rail inverter current, A \\
$\mathrm{i}_{\mathrm{dci} 2}$ & $:$ & Negative dc rail inverter current, A \\
$\mathrm{V}_{\mathrm{ar}}, \mathrm{V}_{\mathrm{br}}, \mathrm{v}_{\mathrm{cr}}$ & $:$ & Rectifier ac input phase voltages, V \\
$\mathrm{i}_{\mathrm{ar}}, \mathrm{i}_{\mathrm{br}}, \mathrm{i}_{\mathrm{cr}}$ & $:$ & Rectifier ac input phase currents, A \\
$\mathrm{V}_{\mathrm{a} 0}, \mathrm{v}_{\mathrm{b} 0}, \mathrm{v}_{\mathrm{c} 0}$ & $:$ & Pole voltages, $\mathrm{V}$ \\
$\theta_{\mathrm{r}}$ & $:$ & Rotor angle, rad \\
& & \\
\hline
\end{tabular}

\section{Introduction}

The development of renewable energy sources has attracted considerable interest in recent years primarily due to concerns about the environment pollution caused by the burning of fossil fuels, and its continually diminishing reserves. This is further fueled by public uneasiness with the safety aspects of power generation using nuclear energy. Currently, obtaining electricity from the wind offers the cheapest economic perspectives of renewable energy sources, wherein, grid connected induction generators are very popular. However, variable speed systems integrated with power electronic interfaces are becoming popular due to their capability of extracting optimal energy capture, reduced mechanical stresses and aerodynamic noise[1], [2].

Generally, a constant speed wind turbine is designed to operate at maximum efficiency for one wind speed that will give the optimum tip-speed ratio for the rotor airfoil. For optimum energy extraction, the speed of the turbine should be varied with wind speed so that the optimum tip-speed ratio is maintained[3]. Power electronics offers most effective method for providing variable speed operation. 


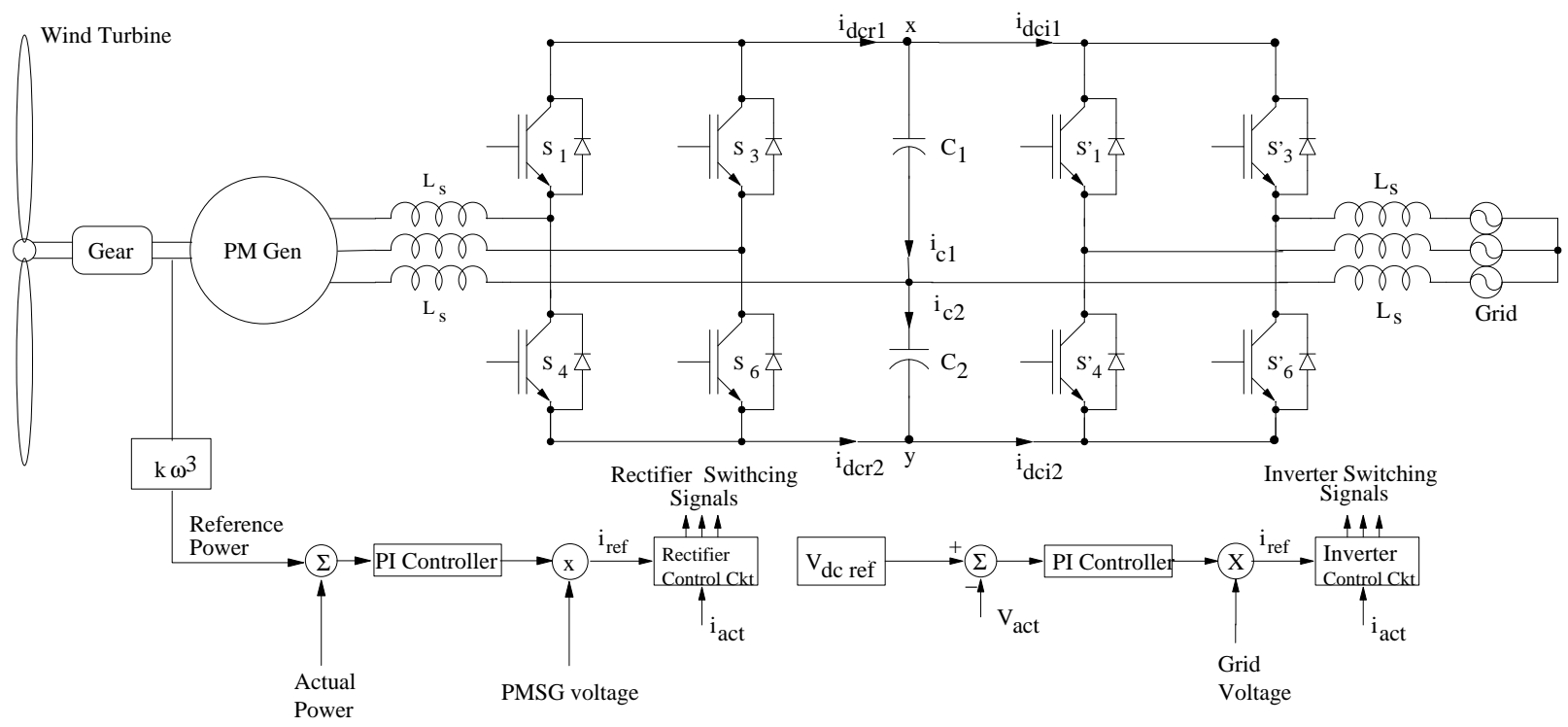

Figure 1. Schematic diagram of the simulated system

Modeling, simulation and experimental verification of a utility interactive wind energy conversion scheme with an asynchronous link is presented in [4]. The scheme consists of a diode bridge rectifier and a line commutated inverter using SCRs. TUTSIM has been used for the simulation of the whole system. Maximum power point tracker is implemented by relating the maximum power available from the wind turbine to the wind velocity, which requires the measurement of wind velocity. But this measurement is difficult in practice. The maximum power is extracted by controlling the triggering angle of the inverter.

A fuzzy logic controlled power electronic system for variable speed wind energy conversion sytem is presented in [5]. This scheme consists of two PWM converters for ac-dc-ac power conversion, dc link voltage maintained constant. Simulation of the system is carried out based on the asssumption that the generator and power electronic system can be represented by a first order lag with a typical time constant of $50 \mathrm{msec}$. The maximum power is extracted by controlling reaction torque of the generator using a fuzzy logic controller.

Application of VSI based power electronic sytems for interfacing variable voltage dc sources to the grid, such as, a variable speed wind power conversion system is presented in [6]. Various system configurations and switching strategies are examined by analysis, simulation and experimental methods. PSPICE is used for simulation of the power electronic systems. Maximum power is extracted from the wind turbine by varying the dc link voltage.

In this paper, a VSWECS consisting of PMSG, two B-4 PWM converters and a MPPT is considered. Figure 1 shows the schematic diagram of the system which is being investigated. In order to improve the efficiency and decrease the cost of power converters, B-4 PWM converters[7] are used instead of B-6 PWM converters. There are only eight switches and two dc link capacitors, instead of twelve switches and one dc link capacitor.
State-space model of each element of the sysem is developed separately, and then they are integrated to simulate the whole system. Power converters are modeled based on switching function concept[8]. The developed mathematical model of the full system can easily be adapted for studying different control strategies. Both magnitude and frequency of the voltage and current of wind turbine driven PMSG are variable in nature. Output power from the PM generator is first converted into dc and then it is fed to the grid. Both the conversions are performed at unity power factor and the dc link voltage is kept constant. MPPT extracts optimum power from the wind turbine from cut-in to rated wind velocities, by sensing only rotational speed of the turbine. The complete system is simulated for various wind velocities using MATLAB/SIMULINK.

The paper is organized as follows. In section 2 mathematical modelling of each element of VSWECS is presented. Control strategy is discussed in section 3 . Section 4 gives simulation results and conclusions are presented in Section 5.

\section{Mathematical modeling of VSWECS}

\section{Wind turbine characteristics}

Wind turbine is characterized by the nondimensional curve of coefficient of performance $C_{p}$ as a function of tip-speed ratio $\lambda$. It can be defined as follows:

$$
\lambda=\frac{\mathrm{r} \omega}{\mathrm{v}}
$$

The power coefficient $\mathrm{C}_{\mathrm{p}}$ varies with tip-speed ratio $\lambda$. The $C_{p}$ versus $\lambda$ characteristics of the turbine used for the study is presented in figure 2 . This characteristic can be approximated by a polynomial as given below [9]:

$$
\begin{aligned}
\mathrm{C}_{\mathrm{p}} & =0.043-0.108 \lambda+0.146 \lambda^{2}-0.0602 \lambda^{3} \\
& +0.0104 \lambda^{4}-0.0006 \lambda^{5}
\end{aligned}
$$




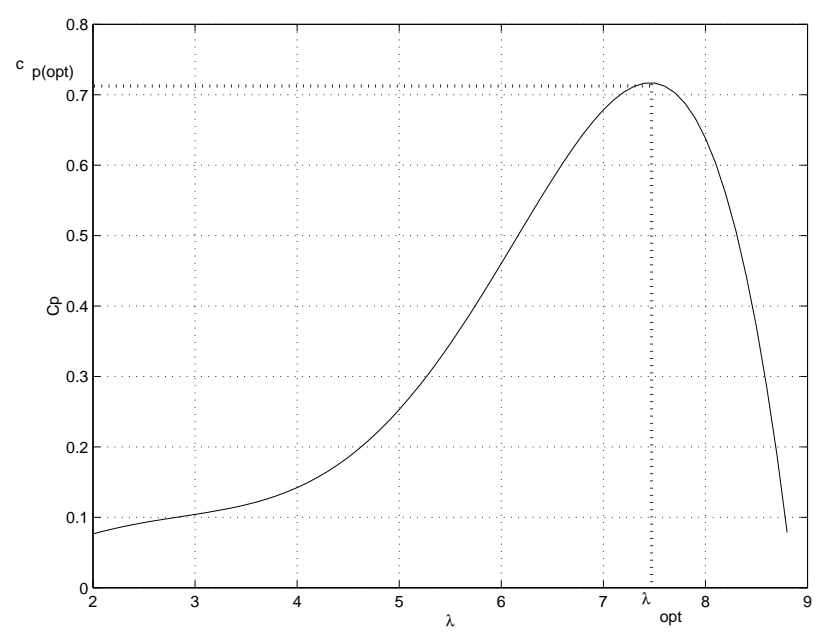

Figure $2 . \mathrm{C}_{\mathrm{p}}$ versus $\lambda$ characteristics

The torque coefficient is defined as $\mathrm{C}_{\mathrm{t}}=\frac{\mathrm{C}_{\mathrm{p}}(\lambda)}{\lambda}$.

The output power of the wind turbine, $p$ is calculated as

$$
\mathrm{p}_{\mathrm{t}}=0.5 \mathrm{C}_{\mathrm{p}}(\lambda) \rho A v^{3}
$$

Substituting $\lambda$ from (1), equation (3) becomes

$$
\mathrm{p}_{\mathrm{t}}=0.5 \rho \mathrm{C}_{\mathrm{p}} \pi \frac{\mathrm{r}^{5} \omega^{3}}{\lambda^{3}}
$$

In order to extract optimum power from the wind turbine, $\mathrm{C}_{\mathrm{p}}=\mathrm{C}_{\mathrm{p}(\text { opt })}$. The corresponding power is given by

$$
\begin{aligned}
\mathrm{P}_{\mathrm{opt}} & =0.5 \rho \mathrm{C}_{\mathrm{p}(\mathrm{opt})} \pi \frac{\mathrm{r}^{5} \omega^{3}}{\lambda^{3}{ }_{\mathrm{opt}}} \\
& =\mathrm{k} \omega^{3}
\end{aligned}
$$

Hence by measuring the rotor speed of the wind turbine, it is possible to operate it at the optimum tipspeed ratio.

It can be observed from figure 2 that $\mathrm{C}_{\mathrm{p}}$ is maximum when $\lambda$ is approximately equal to 7.5 , which is more than the Betz limit, due to polynomial approximation of the actual characteristics.

The torque developed by the wind turbine can be expressed as

$$
t_{t}=\frac{p_{t}}{\omega}
$$

Combining equations 7, 3 and 1 the expression for torque may be written as

$$
\mathrm{t}_{\mathrm{t}}=0.5 \rho \mathrm{Ar} \frac{\mathrm{C}_{\mathrm{p}}(\lambda)}{\lambda} \mathrm{v}^{2}
$$

Equations (1), (2) and (8) are used to simulate the wind turbine.

Figure 3 depicts the relationship between the output power and rotor speed for various wind velocities for the simulated wind turbine

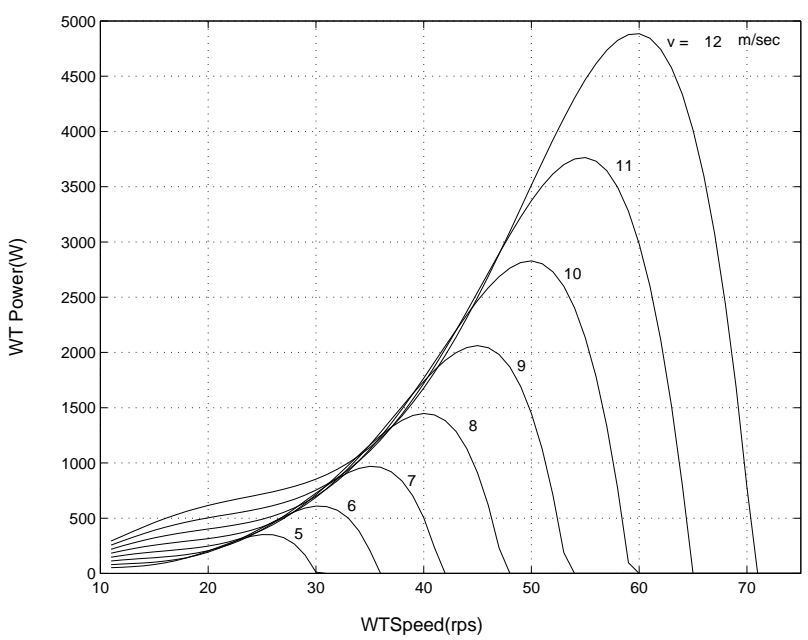

Figure 3. Turbine output power versus rotor speed

$P M S G$

The wind turbine driven PMSG can be represented in the rotor reference frame as:

$$
\begin{aligned}
& \mathrm{v}_{\mathrm{qg}}=-\left(\mathrm{R}_{\mathrm{s}}+\mathrm{L}_{\mathrm{q}} \mathrm{p}\right) \mathrm{i}_{\mathrm{q}}-\omega_{\mathrm{r}} \mathrm{L}_{\mathrm{d}} \mathrm{i}_{\mathrm{d}}+\omega_{\mathrm{r}} \lambda_{\mathrm{m}} \\
& \mathrm{v}_{\mathrm{dg}}=-\left(\mathrm{R}_{\mathrm{s}}+\mathrm{L}_{\mathrm{d}} \mathrm{p}\right) \mathrm{i}_{\mathrm{d}}+\omega_{\mathrm{r}} \mathrm{L}_{\mathrm{q}} \mathrm{i}_{\mathrm{q}} \\
& \mathrm{t}_{\mathrm{e}}=\frac{3 \mathrm{P}}{4}\left[\mathrm{i}_{\mathrm{d}} \mathrm{i}_{\mathrm{q}}\left(\mathrm{L}_{\mathrm{q}}-\mathrm{L}_{\mathrm{d}}\right)+\lambda_{\mathrm{m}} \mathrm{i}_{\mathrm{q}}\right] \\
& \mathrm{p} \omega_{\mathrm{r}}=\frac{\mathrm{P}}{2 \mathrm{~J}}\left(\mathrm{t}_{\mathrm{m}}-\mathrm{t}_{\mathrm{e}}\right) \\
& \mathrm{p} \theta_{\mathrm{r}}=\omega_{\mathrm{r}}
\end{aligned}
$$

The relation between the rotor angular velocity of the generator and the mechanical angular velocity of the wind turbine rotor is expressed as

$$
\omega=\frac{2 \omega_{\mathrm{r}}}{\mathrm{PG}}
$$

Similarly, torque developed by the turbine and the input torque to the generator $t_{\mathrm{m}}$ is expressed as

$$
\mathrm{t}_{\mathrm{m}}=\frac{\mathrm{t}_{\mathrm{t}}}{\mathrm{G}}
$$

The d-q components of generator currents feeding PWM rectifier can be calculated as follows:

$$
\begin{aligned}
& \mathrm{pi}_{\mathrm{q}}=\frac{1}{\mathrm{~L}_{\mathrm{sr}}+\mathrm{L}_{\mathrm{q}}}\left[-\mathrm{R}_{\mathrm{s}} \mathrm{i}_{\mathrm{q}}-\omega_{\mathrm{r}} \mathrm{i}_{\mathrm{d}}\left(\mathrm{L}_{\mathrm{sr}}+\mathrm{L}_{\mathrm{d}}\right)+\omega_{\mathrm{r}} \lambda_{\mathrm{m}}+\mathrm{v}_{\mathrm{qr}}\right] \\
& \mathrm{pi}_{\mathrm{d}}=\frac{1}{\mathrm{~L}_{\mathrm{sr}}+\mathrm{L}_{\mathrm{d}}}\left[-\mathrm{R}_{\mathrm{s}} \mathrm{i}_{\mathrm{d}}+\omega_{\mathrm{r}} \mathrm{i}_{\mathrm{q}}\left(\mathrm{L}_{\mathrm{sr}}+\mathrm{L}_{\mathrm{q}}\right)+\mathrm{v}_{\mathrm{dr}}\right]
\end{aligned}
$$

Solving above equations, $\mathrm{i}_{\mathrm{q}}$ and $\mathrm{i}_{\mathrm{d}}$ are obtained and then they are transformed to stationary reference frame.

\section{PWM Rectifier}

Each switch of B-4 converters is represented as binary resistance. The value of this resistance is infinite if 
the switch is 'off' and zero if it is 'on'. For the figure 1, the following equations are obtained:

$$
\begin{aligned}
& \mathrm{v}_{\mathrm{ar}}=\frac{1}{3}\left(\mathrm{v}_{\mathrm{b} 0}+\mathrm{v}_{\mathrm{c} 0}-2 \mathrm{v}_{\mathrm{a} 0}\right) \\
& \mathrm{v}_{\mathrm{br}}=\frac{1}{3}\left(\mathrm{v}_{\mathrm{c} 0}+\mathrm{v}_{\mathrm{a} 0}-2 \mathrm{v}_{\mathrm{b} 0}\right) \\
& \mathrm{v}_{\mathrm{cr}}=\frac{1}{3}\left(\mathrm{v}_{\mathrm{a} 0}+\mathrm{v}_{\mathrm{b} 0}-2 \mathrm{v}_{\mathrm{c} 0}\right) \\
& \mathrm{v}_{\mathrm{a} 0}=\left(\mathrm{v}_{\mathrm{c} 1}+\mathrm{v}_{\mathrm{c} 2}\right) \mathrm{S}_{\mathrm{a}} \\
& \mathrm{v}_{\mathrm{b} 0}=\left(\mathrm{v}_{\mathrm{c} 1}+\mathrm{v}_{\mathrm{c} 2}\right) \mathrm{S}_{\mathrm{b}} \\
& \mathrm{v}_{\mathrm{c} 0}=\mathrm{v}_{\mathrm{c} 2}
\end{aligned}
$$

The currents are given by:

$$
\begin{aligned}
& \mathrm{i}_{\text {der1 }}=\mathrm{i}_{\text {ar }} \mathrm{S}_{\mathrm{a}}+\mathrm{i}_{\mathrm{br}} \mathrm{S}_{\mathrm{b}} \\
& \mathrm{i}_{\text {der } 2}=\left(1-\mathrm{S}_{\mathrm{a}}\right) \mathrm{i}_{\mathrm{ar}}+\left(1-\mathrm{S}_{\mathrm{b}}\right) \mathrm{i}_{\mathrm{br}}
\end{aligned}
$$

Applying KCL at nodes ' $x$ ' and ' $y$ ' in figure 1 , the voltages across capacitors and hence the dc link voltage can be determined.

The switching functions for the rectifier are derived using a hysteresis type of current controller. Knowing the switching functions $\left(\mathrm{S}_{\mathrm{a}} \& \mathrm{~S}_{\mathrm{b}}\right)$ and using equations (13)(20), PWM rectifier is simulated.

\section{PWM Inverter}

The procedure for modeling PWM inverter is the same as that of the PWM rectifier. The inverter output phase currents are given by:

$$
\begin{aligned}
& \frac{\mathrm{di}_{\mathrm{ai}}}{\mathrm{dt}}=\frac{1}{\mathrm{~L}_{\mathrm{si}}}\left[\frac{1}{3}\left(2 \mathrm{v}_{\mathrm{a} 0}-\mathrm{v}_{\mathrm{b} 0}-\mathrm{v}_{\mathrm{c} 0}-\mathrm{i}_{\mathrm{ai}} \mathrm{R}-\mathrm{e}_{\mathrm{an}}\right)\right] \\
& \frac{\mathrm{di}_{\mathrm{bi}}}{\mathrm{dt}}=\frac{1}{\mathrm{~L}_{\mathrm{si}}}\left[\frac{1}{3}\left(2 \mathrm{v}_{\mathrm{b} 0}-\mathrm{v}_{\mathrm{c} 0}-\mathrm{v}_{\mathrm{a} 0}-\mathrm{i}_{\mathrm{bi}} \mathrm{R}-\mathrm{e}_{\mathrm{bn}}\right)\right] \\
& \frac{\mathrm{di}{ }_{\mathrm{ci}}}{\mathrm{dt}}=\frac{1}{\mathrm{~L}_{\mathrm{si}}}\left[\frac{1}{3}\left(2 \mathrm{v}_{\mathrm{c} 0}-\mathrm{v}_{\mathrm{b} 0}-\mathrm{v}_{\mathrm{a} 0}-\mathrm{i}_{\mathrm{ci}} \mathrm{R}-\mathrm{e}_{\mathrm{cn}}\right)\right] \\
& \mathrm{i}_{\mathrm{dci} 1}=\mathrm{i}_{\mathrm{ai}} \mathrm{S}_{\mathrm{a}}{ }^{\prime}+\mathrm{i}_{\mathrm{bi}} \mathrm{S}_{\mathrm{b}}{ }^{\prime} \\
& \mathrm{i}_{\mathrm{dci} 1}=\mathrm{i}_{\mathrm{ai}}\left(1-\mathrm{S}_{\mathrm{a}}{ }^{\prime}\right)+\mathrm{i}_{\mathrm{bi}}\left(1-\mathrm{S}_{\mathrm{b}}{ }^{\prime}\right)
\end{aligned}
$$

The switching functions for the inverter are derived using a hysteresis type of current controller. Knowing the switching functions $\left(\mathrm{S}_{\mathrm{a}}{ }^{\prime} \& \mathrm{~S}_{\mathrm{b}}{ }^{\prime}\right)$ and using equations (21)(25), PWM inverter is simulated.

\section{Control Strategy}

\section{PWM Rectifier}

For a given speed of the rotor, the three phase reference currents required for the PWM rectifier are generated by the MPPT. Reference power and actual power are compared and error is processed by a PI controller. The output of PI controller represents the magnitude of the reference currents. These reference currents are in phase with the respective terminal voltages.

\section{PWM Inverter}

A separate controller generates the reference currents required for the PWM inverter. This controller determines the magnitude of the reference current in such a way that the dc link voltage is maintained constant at a desired value. These reference currents are out of phase with the respective grid voltages.

\section{Simulation Results}

In order to validate the mathematical model developed for the VSWECS, simulations studies using MATLAB/SIMULINK are carried out. The various parameters used for the simulation of the system are given in Appendix. Simulated results for wind speeds of $6,8,10$ and $12 \mathrm{~m} / \mathrm{sec}$ under steady state conditions are presented, in figures 3-9.

Figure 4(a) shows phase-A terminal voltage of PMSG, while, figure 4(b) depicts phase-A input current of the rectifier for a wind velocity of $6 \mathrm{~m} / \mathrm{sec}$. It can be

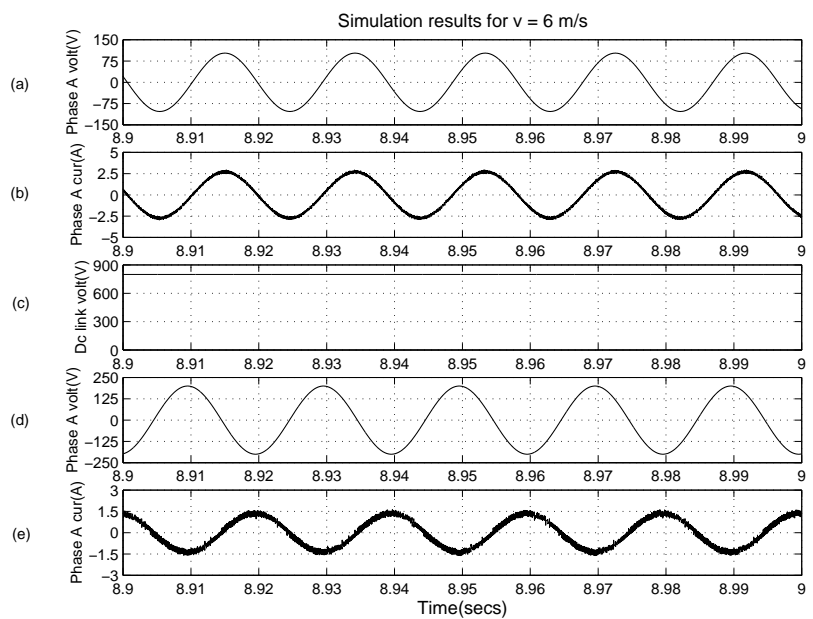

Figure 4. Simulation results for $\mathrm{v}=6 \mathrm{~m} / \mathrm{sec}$

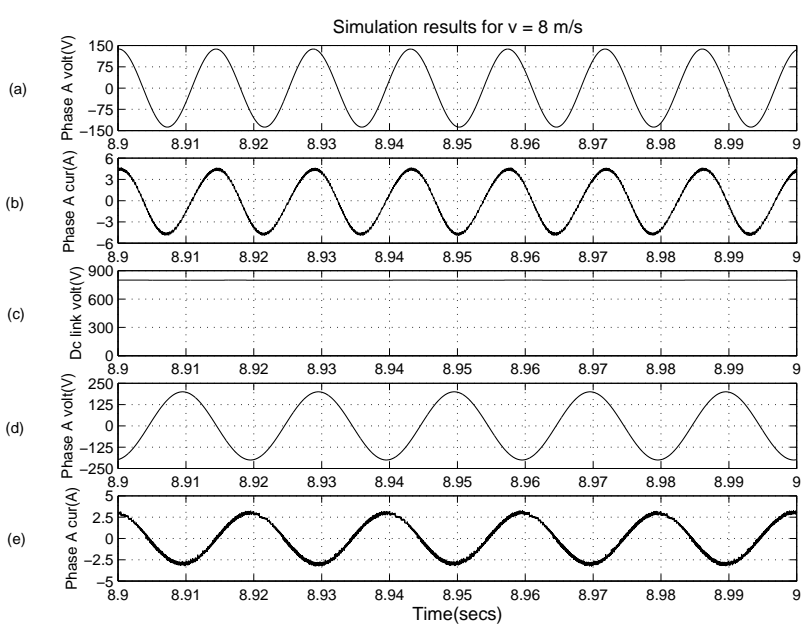

Figure 5. Simulation results for $\mathrm{v}=8 \mathrm{~m} / \mathrm{sec}$ 

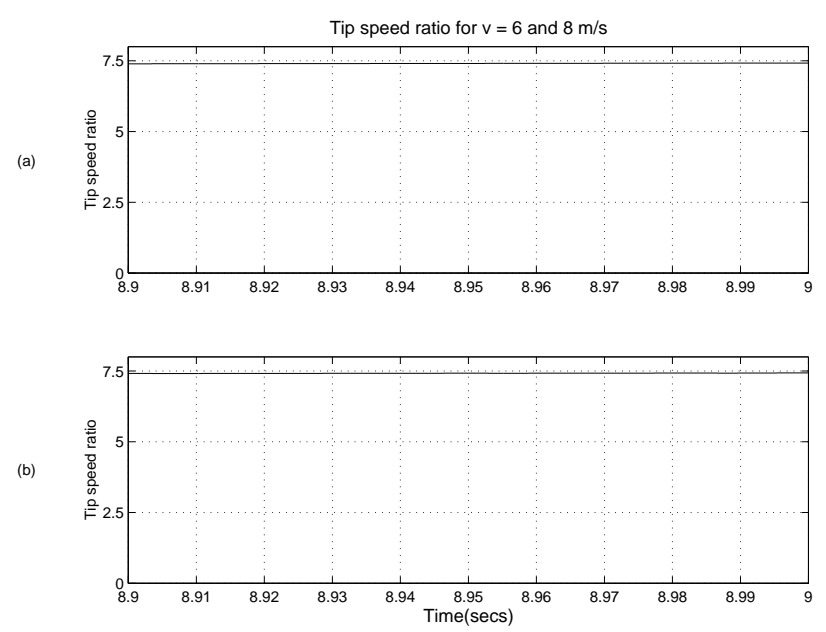

Figure 6. Simulation results for $\mathrm{v}=6$ and $8 \mathrm{~m} / \mathrm{sec}$
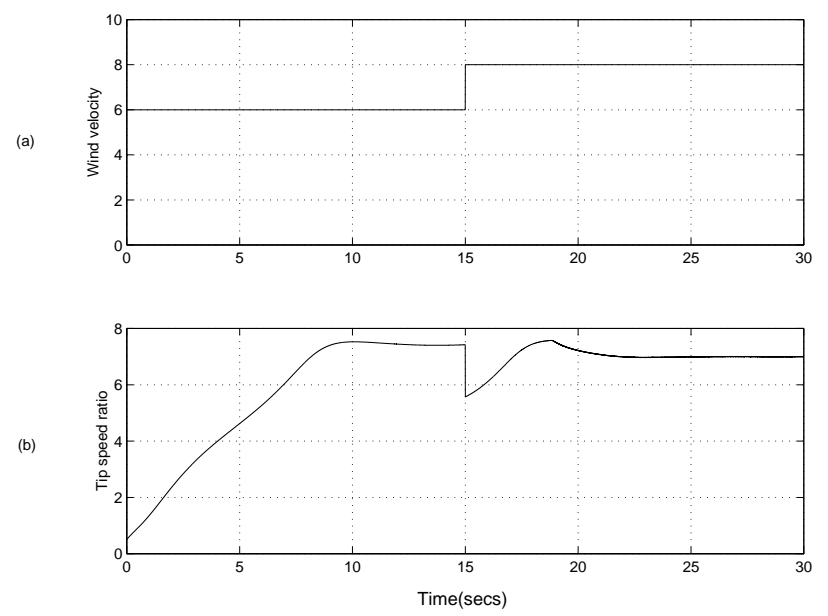

Figure 7. Simulation results for a step change in $\mathrm{v}$

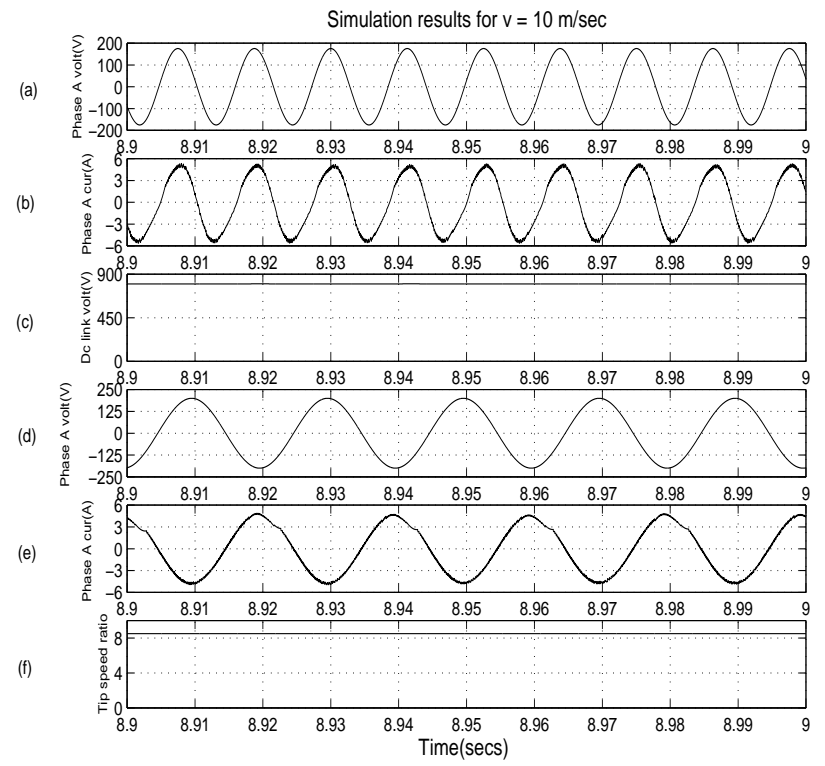

Figure 8. Simulation results for $\mathrm{v}=10 \mathrm{~m} / \mathrm{sec}$

seen that input current of PWM rectifier is in phase with corresponding phase voltage. Figure 4(c) represents dc link voltage, which is maintained constant at $800 \mathrm{~V}$. Figure 4(d) displays phase-A grid voltage, while figure 4(e) exhibits phase-A inverter current. This current is in anti-phase with the corresponding phase voltage.

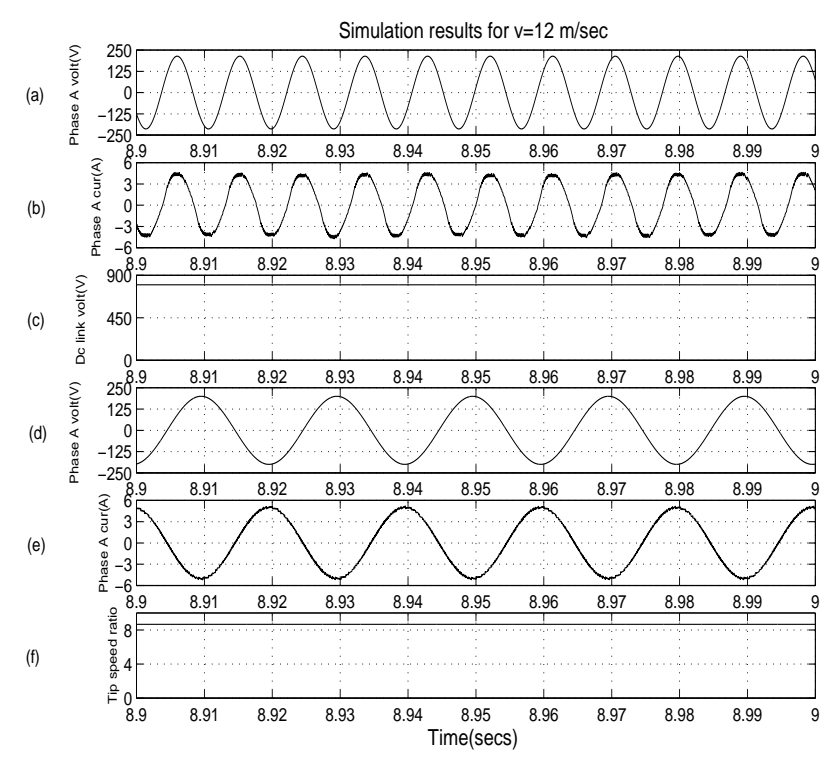

Figure 9. Simulation results for $\mathrm{v}=12 \mathrm{~m} / \mathrm{sec}$

Figure 5 shows the simulation results for wind speed of $8 \mathrm{~m} / \mathrm{sec}$

From figures 4 and 5, it can be observed that, with the increase in wind speed the power fed to the grid also increases which is indicated by increase in magnitude of PMSG phase voltage, rectifier phase current and inverter output phase current.

Figure 6 presents variation of tip-speed ratio $(\lambda)$ with time. Figure 6(a) depicts for a wind speed of $6 \mathrm{~m} / \mathrm{sec}$ while figure $6(\mathrm{~b})$, for a wind speed of $8 \mathrm{~m} / \mathrm{sec}$. It can be seen that the tip-speed ratio is maintained constant at about 7.5 where $C_{p}$ is maximum as shown in figure 2 .

Figure 7 shows the time variations of wind speed and tip-speed ratio. At $\mathrm{t}=15 \mathrm{sec}$, wind speed is changed from 6 to $8 \mathrm{~m} / \mathrm{sec}$. However tip-speed ratio is maintained at $\lambda_{\text {(opt) }}$ in steady state conditions.

Figures 8 and 9 show the simulation results for a wind speeds of 10 and $12 \mathrm{~m} / \mathrm{sec}$. For these wind speeds, at $\mathrm{C}_{\mathrm{p}(\max )}$, turbine output power is more than the rated power i.e. $1500 \mathrm{~W}$. However, output power is limited to the rated power. Figures 8(a) and 9(a) show phase-A terminal voltage of PMSG, while figures 8(b) and 9(b) depict phase-A input current of the rectifier. Figures $8(\mathrm{c})$ and 9 (c) represent dc link voltage, which is maintained constant at $800 \mathrm{~V}$. Figures 8(d) and 9(d) display phase-A grid voltage, while figures 8(e) and 9(e) exhibit phase-A inverter current. The variation of tip speed ratio is shown in figures $8(\mathrm{f})$ and $9(\mathrm{f})$.

Since these wind speeds are greater than the rated wind speed $(\sim 8 \mathrm{~m} / \mathrm{sec}$, from figure 3$)$, MPPT will not track maximum power point. Instead, it makes wind turbine to operate at lower value of $\mathrm{C}_{\mathrm{p}}$.

\section{Conclusions}

In this paper, modeling and simulation of a grid connected variable speed wind energy conversion system is presented. In order to improve the efficiency and decrease the cost of power converters, B-4 PWM converters are used instead of B-6 PWM converters. 
There are only eight switches and two dc link capacitors, instead of twelve switches and one dc link capacitor. Mathematical model of each element of the system is developed separately and then they are interconnected to simulate the whole system for various wind velocities. Switching functions are used to model the power converters. The complete system has been simulated using MATLAB/SIMULINK, and simulation results are presented for four wind speeds. From the simulation results, it can be seen that maximum power is being extracted for all wind speeds from cut-in to rated speeds. Power converters are operating at unity power factor with minimum harmonic distortion. With minimum modification in the model, the whole system can be simulated for different control strategies.

\section{Appendix}

\section{Simulation parameters:}

\section{Wind turbine:}

Air density $\rho=1.08$, radius $=1.525 \mathrm{~m}$, initial speed of the wind turbine $=20 \mathrm{rps}$, gear ratio $=5$, rated power $=1500 \mathrm{~W}$, rated wind velocity $\sim 8 \mathrm{~m} / \mathrm{sec}$.

\section{PMSG:}

1-HP, $208 \mathrm{~V}, 60 \mathrm{~Hz}, \mathrm{P}=4, \mathrm{R}_{\mathrm{s}}=1.5 \Omega, \mathrm{L}_{\mathrm{d}}=\mathrm{L}_{\mathrm{q}}=0.05 \mathrm{H}$, $\lambda_{\mathrm{m}}=0.314 \mathrm{volts} / \mathrm{rad} / \mathrm{sec}$, combined $\mathrm{J}$ of the wind turbine and generator $=2 \mathrm{~kg} / \mathrm{m}^{2}$.

\section{PWM Rectifier:}

$\mathrm{L}_{\mathrm{sr}}=1 \mathrm{mH}, \delta \mathrm{i}=0.10 \mathrm{~A}, \mathrm{C}_{1}=\mathrm{C}_{2}=0.005 \mathrm{~F}$.

\section{PWM Inverter:}

$\mathrm{R}=0.5 \Omega, \mathrm{L}_{\mathrm{si}}=0.05 \mathrm{H}, \delta \mathrm{i}=0.10 \mathrm{~A}$, grid voltage $=140$ $\mathrm{V} /$ phase, $\mathrm{dc}$ link voltage $=800 \mathrm{~V}$.
[1] Thomas Ackermann and Lennart Söder, 'An overview of wind energy status-2002', Renewable \& Sustainable Energy Reviews, pp.67-128, June, 2002.

[2] R. David Richardson and Gerald M McNerney, 'Wind Energy Systems', Proceedings of the IEEE, vol. 81, No. 3, pp. 378-389, 1993.

[3] Gary L Johnson, 'Wind Energy Systems', Prentice Hall Inc., Englewood Cliff, NJ, 1985.

[4] R. M. Hilloowala, and A. M. Sharaf, 'A Utility Interactive Wind Energy Conversion Scheme with an Asynchronous DC Link using a supplementary control loop', IEEE Trans. on Energy Conv., vol.9, No.3, pp.558-563, Sept 1994.

[5] Z. Chen, S. Arnalte Gomez and M McCormick, 'A Fuzzy logic controlled power electronic system for variable speed wind energy conversion systems', Conference Publication No.475, Power Electronics and Variable speed Drives,pp. 114-119, IEE, Sept. 2000.

[6] Z. Chen and E.Spooner, 'Voltage source inverters for high power variable voltage DC power sources', IEE Proc, Gener. Transm. Distrib., vol.148, No.5, pp. 439-447, Sept.2001.

[7] G. T. Kim and T. A. Lipo, 'VSI-PWM Rectifier/Inverter system with reduced switch count' IEEE Tran. on Ind. Appl., vol. 32, No. 6, pp.13311337, Nov/Dec, 1996.

[8] Byoung-Kuk Lee and Mehradad Ehasani, 'A Simplified functional simulation model for three phase VSI using switching function concepts', IEEE Trans. on Industrial Electronics, vol. 48, No.2, pp.309-321, April, 2001.

[9] Bogdan S Borowy and Z. M. Salameh, 'Dynamic response of a stand-alone wind energy conversion system with battery energy storage to a wind gust', IEEE Trans. on Energy Conv., vol.12, No.1, pp.7378, March, 1997.

\section{References}

